\title{
Cube-root 空間と色順応補正
}

\author{
池田紘一。冲山昌春・小原清成 \\ (束京理科大学)
}

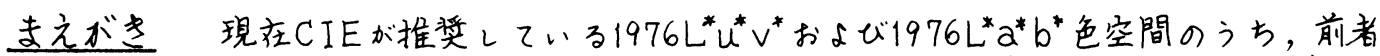
はXYZ系からの1次变换であるという利点，きた，MacAdamの并别椅月に関てて昼光D65 の下でははぼよい均整度を示すという特徵をもっているが，色順㐫に対する補正がなされ

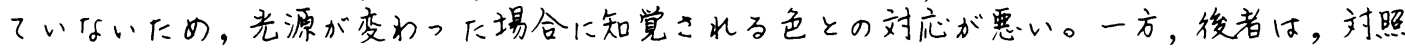
的に，非線形变換であり，弁别棈円に関して多少不均一性を示すが，色順忘を考虑して作 られているため，光源が变化しても対応色の関係が視覚系の色知觉とはぼよい一致を示す。 修整Cube-root 色空間と視賞心理实験方法修整 L゙ $u^{*} v^{*}(2)$ おびReillyの係数による修 整Cube-rootの各色空間を表わ可式を认下に示す。

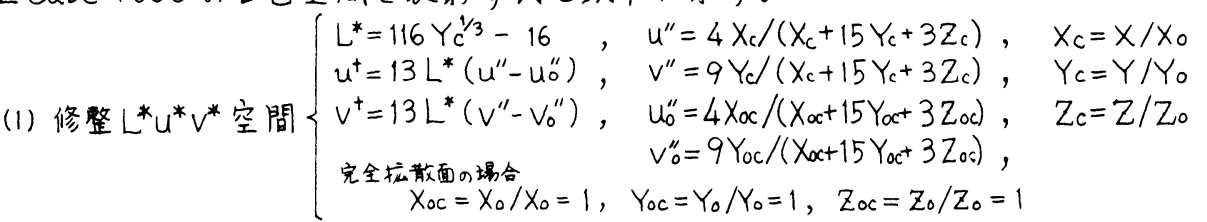

(2) 修整Cube-root 空間 $\left\{\begin{array}{lll}L=25.29\left(100 G / G_{0}\right)^{1 / 3}-18.38 & , \quad & R=1.1084 X+0.0852 Y-0.1454 Z \\ a=106.0\left[\left(100 R / R_{0}\right)^{1 / 3}-\left(100 G / G_{0}\right)^{1 / 3}\right], & G=-0.0010 X+1.0005 Y+0.0004 Z \\ b=42.34\left[\left(100 G / G_{0}\right)^{1 / 3}-\left(100 B / B_{0}\right)^{1 / 3}\right], & B=-0.0062 X+0.0394 Y+0.8192 Z\end{array}\right.$

$R_{0}=1.1084 X_{0}+0.0852 Y_{0}-0.1454 Z_{0}, G_{0}=-0.0010 X_{0}+1.0005 Y_{0}+0.0004 Z_{0}, B_{0}=-0.0062 X_{0}+0.0394 Y_{0}+0.8192 Z_{0}$

にだし，X,Y,Zは物体色の三刺激值，X。，Yo, Z。は完全搪散面の照明光による三刺激值。 式(2)は本来のCube-root空間の表式の中で，R，G，Bの項を乥れ炎北照明光の特性を表わす Ro,Go, Borの比，すなわち，100R/Ro,100G/Go,100B/B。で置换したものにはかならない。これによ つて光源が变化しに埸合に対する色順岕補正の要素を含むことにはる。斿お，座標原点は

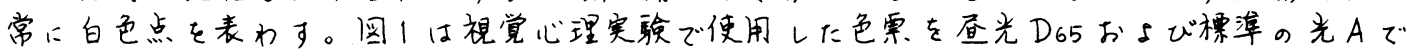
照明した場合の座標を示したしのである。同图(a)はCIELUV空間の㻛合で，色順㐫補正が

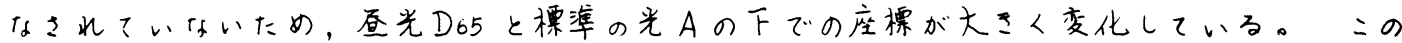
CIELUUV空間へAdams-Nickersonの考えを導入して色順㐫補正を考覤したのが(C)で，その 効果がA光下で顕著に表われている。一方，(b)，(d)はA光下で似下配列を示しており，特 に(d)の修整Cube-root空間ではD65とA光の下での彩度成分の变化が最も小さいとい了特

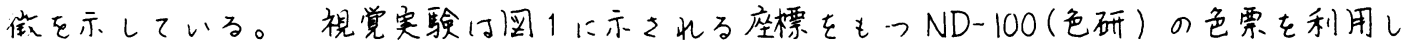

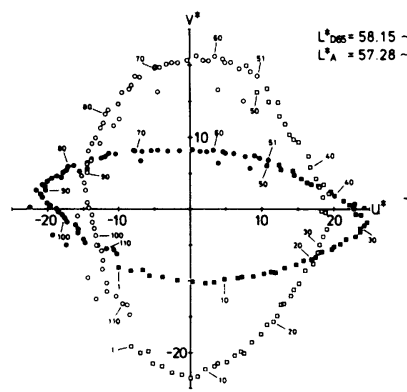

(a) CIE LUV $\mathbf{g m}$

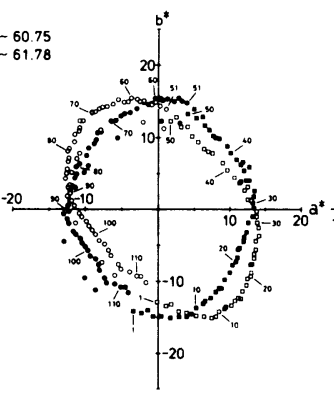

(b) CIE LAB $\$ M$

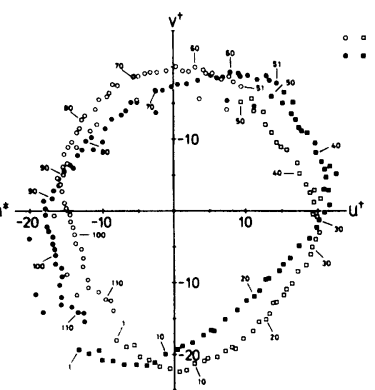

(c) H\& เพ $\$$

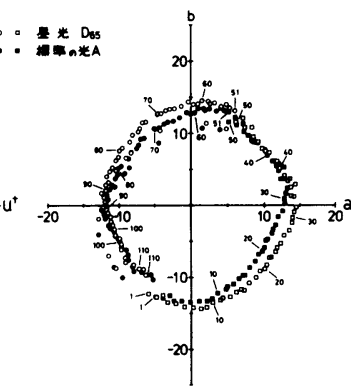

(d) Cube-root क्ष

圆1使用した色票の各测色空間での座標 
1て比率部定法によって行なった。钼测者は男性了 名，照明光はシミュレートした荲光D65と標準の 光Aである。

知党される色差と測色上の色差との相閏 相

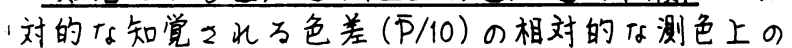
${ }^{5}$ 色差( $\left(A E / \Delta E_{0}\right)$ に対する相関の散布图を修整 L゙ $U^{*} V^{*}$ お よU゙修整Cube-root空間について图2に示す。紙 面の関係でCIELUVおよU゙LAB空間についての国(3) は省略するが，歪光D65の下では，いずれの空間 にフいても優劣がつけがたく，ほぼよい 0.80 の相閶を示している。を, 標隼の光Aの下 でも同样であるが，CIELUUV $(\rho=0.85)$ が他の修整 Cube-root $(\rho=0.72)$, CIE.LAB $(\rho=0.71)$, 修整 $L^{*} u^{*} v^{*}$ $(\rho=0.65)$ と比べてわずかによいといえる。

光源が变わつた場合の测色上の色差の相関 この相関は图1からある程度予想三れるが，图了 に示すように，修整Cube-rootが最も高い相関( =0.99）を示し，光源の变化に对する色差の恒常性と いう結果とよい対心を示している。他は順次，修

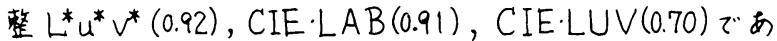
るが，CIE.LUVが最も低いのは色順応補正が政方 れていないからである。

光源が变わった場合の測色单位色差あたりの知 賞される色差の相関相対的坆知賞旦れる色差

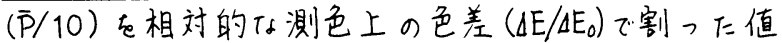
を測色单位色差あたyの知喾亡水子色差と定義し, A光の下での艺就のD65光の下での学京に対する 相関を示したのが图4である。これは光源が变わ つた埸合の知觉をれる色差と测色上の色差との対 忘関係を示しており，修整Cube-rootが4空間の 中で相関が最も高く( $\rho=0.90)$, 順次, CIE.LAB $(0.78)$ 椙 修整 L*U* $U^{*}(0.76), C I E \cdot L U V(0.35)$ を示している。

二の埸合も，CIE·LUVの相関が立わ悪いのは 前項と同心゙理由からである。

あとがき 以上の色差に関する相互比較から, 掸 色順㐫補正を施した色空間，特に修整Cube-root焦 空間は知觉上れる色差と测色上の色差との対㐫に おいて大变よい結果を示している。广お，視觉心” 理实験で使用した色票の彩度が2〜4と低い所の ものなのでより彩度の高い色についても調心る 必要がある。

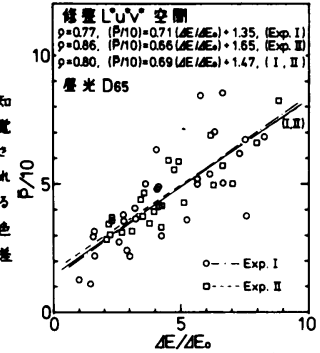

(a)
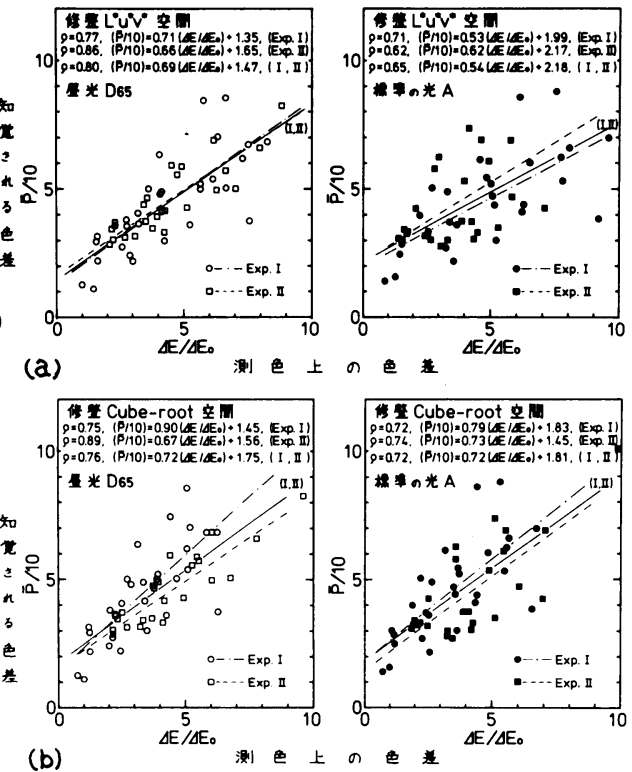

四2 知覚之れる色差と测色上の色差との相関
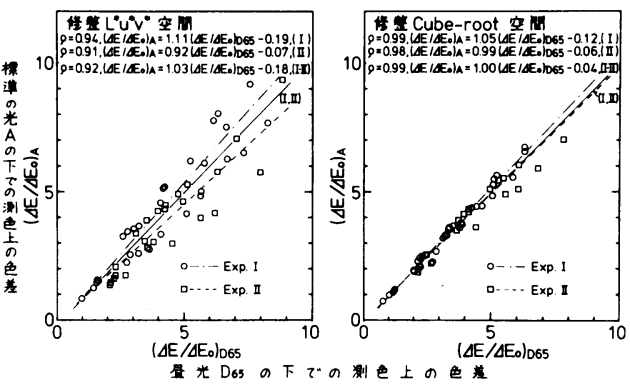

図3光源が变わった場合の測色上の色差の相閶
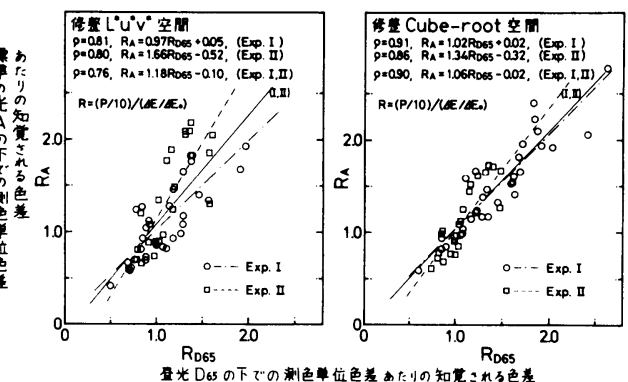

图4光源が变わた場合の測色单位色差 あたりの知觉される色差の相関

参考文献

(1)池田：テレビジョン学会技術報告, Vol. 3, No. 24,p.47，(1979）

(2)池田, 中山, 小原: 色彩学会誌, Vol.4, No.1, p.9, (1979)

(3) K.IKEDA, M.NAKAYAMA and K.OBARA : Presented at CIE 19 th Session, TC-1.3, (1979) 